\title{
DEMOCRACY EDUCATION THROUGH THE DEVELOPMENT OF PESANTREN CULTURE
}

\author{
Muh. Nur Rochim Maksum ${ }^{1 *}$, Musa Asy'arie ${ }^{2}$, Abdullah Aly ${ }^{3}$ \\ ${ }^{1 *}$ Doctor Candidate, Universitas Muhammadiyah Surakarta, Indonesia; ${ }^{2}$ Department of Islamic Teacher Training and \\ Education, Universitas Muhammadiyah Surakarta, Indonesia; ${ }^{3}$ Department of Islamic Teacher Training and Education, \\ Universitas Muhammadiyah Surakarta, Indonesia. \\ Email: ${ }^{1 *}$ muhnurrochim23@gmail.com, ${ }^{2}$ musapadma@gmail.com, ${ }^{3}$ aa130@ums.ac.id \\ Article History: Received on $6^{\text {th }}$ May 2020, Revised on $18^{\text {th }}$ June 2020, Published on $01^{\text {st }}$ July 2020
}

\section{Abstract}

Purpose of the study: The study aims to explore the development of Islamic boarding school culture as the basis of actualization democracy education in Pesantren.

Methodology: The study uses a qualitative approach with interviews and observations and documentation as a key research tool for data collection. As for the participation in this research is Islamic Modern Boarding School Assalaam Surakarta (PPMI Assalaam).

Main Findings: This study found three main themes to actualize democracy education through the development of the culture of Pesantren, namely 1) establishing the identity of Pesantren 2) created a vision and mission of Pesantren 3) integrating essential and instrumental values of pesantren with democratic values that are compatible with Islam.

Applications: This study can be useful to increase knowledge treasures and to be a prototype for the actualization of democracy education in educational institutions, especially in pesantren through the development of the democratic pesantren culture.

Novelty: This study created the basis and prototype of the actualization of democracy education in the school environment and especially the pesantren, through the building of the identity of Pesantren, creating the vision and mission of Pesantren and the integration of essential values and instrumental of pesantren with the values of democracy that is compatible with Islam. Carrying out the orders of the vision, mission, and objectives of Indonesian national education shown to eliminate education discrimination, and to make students able to live in the society and system of democracy, so important step of the development of school culture as the basis of it all.

Keywords: Education, Democracy, Pesantren Culture, Democracy Development, Vision, Mission.

\section{INTRODUCTION}

The development of democracy in the events of Indonesian society since the Reformation has walked. Democracy has evolved a lot in many countries because democratic countries are growing higher innovations than autocracy-based countries (Gao et al., 2017).

The democracy that runs in Indonesia is considered to be a lot not under the ideality of democracy. The values, principles, and rules of the nature of democracy have not been able to be internalized by the nation properly and mindfully. Democracy in Indonesia is faced with several major challenges including the corruption of military security, the protection of minority rights, and Islamic radicalism. (Freedman \& Tiburzi, 2012)

Seeing the reality of the aberrations of democratic values occurring in Indonesia shows the lack of understanding and the actualization of democratic values in national and state life. It is necessary to invest in the attitude of democracy early and lasts for a long period. Education has a strong correlation with democracy (Glaeser et al., 2006; Coffe, 2014) in other words has causality. (Apergis, 2017) Therefore, the education of democracy is implemented, in every educational institution in Indonesia, with the main objective is to prepare citizens who think critically and act democratically (Gandal \& Finn, 1992).

Educational institutions including Pesantren became the main agent in the actualization of Democracy Education (Azra, 2015) so far need to be examined by the implementation, especially attributed to the law No. 20 the year 2003 about the national education system of article Three, and the Law of the Republic of Indonesia, chapter III, article 4, verse 1, about the education system in Indonesia. This research needs to be done because educational institutions need the latest data on the implementation of an urgent democratic education to be renewed and accountable.

The education of democracy in educational institutions must be implemented holistically, by involving all elements in educational institutions. To conduct a holistic education of democracy in the educational institution, it will not be separated from the three essential elements of the institution itself, namely, structure, culture and, process (Zamroni, 2011). Thus, research that emphasizes the structure, culture, and process of democracy education in educational institutions, is expected to acquire a holistic education profile of democracy in education institutions. The research focuses on one aspect of the three aspects of the school culture. 
Boarding school at the beginning of its emergence is a traditional Islamic education system in dormitories in Indonesia (Patriadi et al., 2015). Pesantren stands in conjunction with the proliferation of Western civilization that rejects revelation or religion as one of the epistemologies of science and restriction of the epistemology of science only on the senses and mind alone. Paryono (2018) As an institution that has stood to educate the nation from difficult times, when the times of the struggle against the colonial and the center of study that survive until the present, (Wekke, 2014) then the Pesantren should do the transformation of the education of democratized democracy towards the holistic, by making structures, cultures, and processes in the pesantren that is democratical. But in practice, it is not easy to do by the pesantren, especially the traditional pesantren (Salafiyah).

The traditional Pesantren as it has been mentioned above has complexity in implementing democracy education. This is because in realizing the structure, culture, and process of democratic characteristics contrary to the principle of traditional pesantren in general. Its complexity comes down to two main things: the central role of a Kiyai and his founding orientation. Kiyai is a pemimipin pesantren that is recognized by the public and has good religious knowledge (Indrawati, 2014). Kiyai on a traditional pesantren became the center of all movements of a pesantren. Kiyai is an inspiration and a source of knowledge for absolute students. One of the effective ways to turn an educational institution into a democratic is by changing the leadership style of the headmaster. (Jwan, 2010) The central position of a Kiyai is generally based on Kiyai is the pioneer, maintainer, caretaker, even as the sole proprietor of Pesantren (Ramli, 2017).

The complexity of the orientation of traditional boarding schools, described in four dimensions, the status of students as an object of education, the function of teachers as a transfer of science and indoctrinator, educational material is subjectoriented, and management of Education is centralistic (Zamroni, 2011).

Meanwhile, modern Pesantren (Khalafiyah), which is based on the collective-democratic leadership pattern, there is no role-centered on the Kiyai figure, but it involves the participation of teachers and students to investigate, discover, and exchange knowledge of this matter behind the modern Pesantren has a professional school culture (Schipper et al, 2020) that is why this research takes focus on democracy education in modern Pesantren.

The modern Islamic boarding school of Assalaam Surakarta (in the next description used by PPMI Assalaam), is one of the modern boarding schools in Indonesia, chosen as the object in this study. The election of PPMI Assalaam Surakarta as the object of research is based on the fact that PPMI Assalaam Surakarta has implemented democratic values. The fact is indicated by the establishment of various parties in the planning, implementation, and evaluation of the curriculum PPMI Assalaam Surakarta (Aly, 2011).

\section{LITERATURE REVIEW}

The minimal meaning of democracy that has been generally accepted after World War II is the synthesis of political freedom and political equality (Munck, 2016). Democracy in the journey has a sense of meaning in each place. All such developments are still there are and remain diced, regardless of the typical Western-style as is generally and Latin America in particular (Storm, 2008).

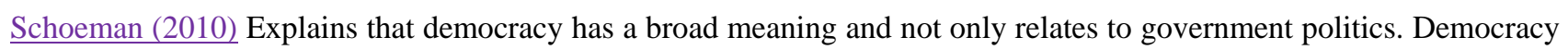
has a meaning as a "way of life" that leads to how a man can live with the community well based on the internalization of democratic values. The point where democracy and education intersect should be a community. This community is then a major place of democracy education. The community needed is a community of living democratic values in it. In the UK, an in-depth study of democracy and education has also been undertaken for more than 13 years to improve the community's understanding of Democracy (McDonnell, 2013). Democracy and education go together inseparably to create the expression of a life together (Quay, 2016).

Azra (2003) argues that democratic education is an effort undertaken as socialization, dissemination, and actualization of concepts and systems, values, culture, and practice of democracy. Democracy education is closely related to the discussion. A teacher engages students and the whole community learns to engage in a discussion with respect, attentiveness, and hope (Preskill, 1997). The development of knowledge and the skills of critical pedagogy are also expected to grow to form a cratic citizen (Giroux, 2009).

The development of democratic culture through the development of discussions is expected to educate the public to be responsible for their voices (Oelkers, 2017). In addition to the above Ubaedillah (2018) saw that the central role of citizenship education is also very important to disseminate the values and culture of democracy to students. Cho (2014) explains based on the analysis of the Korean Barometer survey 2010 showing the whole selector of the young or old Korean, educated, and uneducated college unable to distinguish Democratic and undemocratic regimes. This is due to the lack of development of democratic culture in community life.

Democracy education is currently considered partial because it is only a mere emphasis on the cognitive students but ignores the main factor of the creation of a democratic culture in school. The creation of democratic culture is just as important as the cognitive development of students, each teacher can develop democratic values in all aspects of the overall school life (Hansen, 2015). Karakus (2017) explains that giving students the rights in the school will significantly develop a school's democratic culture. 
Zamroni (2011) explains the education of democracy in the school environment means creating what is happening in the school will support and score students to possess, knowledge, and intelligence democracy, as well as to have a democratic attitude and soul. This suggests that the school should position itself as a miniature of a democratic society of life, so that students can have the opportunity to develop an understanding of pluralistic society and active participation, with an understanding of cooperation, tolerance, rationalizing decisions, and understanding each of the problems of various views (Sanli, 2015).

Garmston \& Wellman (2009) said that school culture is the values and objectives that exist in the school held firmly together, cooperation and assisting each other among the school, together to plan for the future and solve the problems faced. There are with above Aasebø et al., (2015) explaining the school warts are understood as the values, attitudes, relationships, and involvement of students in all school activities.

Pesantren is an Islamic educational institution characterized by boarding, this shows that boarding schools create a community in the learning environment. Based on this, Pesantren has a great opportunity to actualize the education of democracy by forming a rural or small community that can create a culture change by the inhabitants in it (Aubusson et al., 2005), as well as the study of social life in the community (Baise, 2003). It is based on that Islam also matches the values of democracy. (Minkenberg, 2007) and Islamic Religious education aims not only to form a person who fears God (Mulyasa \& Aryani, 2017) but also to eradicate injustice (Waghid, 2014). The development of the democratic culture in the Pesantren can prevent the shift of Islamic education from the inclusive and rational search for all knowledge into a narrower focus on religious knowledge, Without rationality (Sabic-El-Rayess, 2019).

\section{METODOLOGY}

\section{Research Design}

This research uses a qualitative approach. Data collection is done through observation, interviews, and documentation. The place in this research is in Islamic Modern Boarding School Assalaam Surakarta, Central Java, Indonesia which has internalized the culture of democracy in the pesantren and there is a community consisting of hundreds of educators, education personnel and thousands of students with a very diverse background in PPMI Assalaam Surakarta. This research will describe in a detailed reality or phenomenon by providing criticism or assessment of the phenomenon.

\section{Data Validity}

This research uses internal data validity testing by enhancing researchers' diligence, performing observation extensions by re-performing observations, conducting interviews with old or new speakers. Tri angulation, done by stirring the data checking from various sources in various ways, and various time. Check the member by checking the data obtained by research and data. While the validity of the external data of this research using the preparation of research reports is more detailed, systematic, and clear. This study also used the validity of the data Confirmability (certainty), these criteria to obtain the certainty of data received by researchers from the subject of research. This certainty is a record of voice.

\section{Data-Analysis Techniques}

Data analysis is an effort to process all the data that has been obtained in the research into information so that the data can be processed to solve the research problems. Data analysis in qualitative research was conducted before entering the field, during the field, and after the field, with more emphasis on the second process. To analyze the data obtained from the results of the study, used techniques by studying the entire data, reducing data, arranging in units, categorizing data validity checks, and the last data interpretation. Once the data is collected it will be drawn conclusions related to the data obtained.

\section{RESULTS AND DISCUSSION}

Storm (2008) describes democracy in its development experiencing various meanings, but all that development is still appropriate and recognized as the concept of democracy while still keeping the principles of democracy. The meaning of democracy as a "way of life" is now deemed more important than mere understanding in the political system. This is so that people can truly internalize the values of democracy in real-life every day (Schoeman, 2010).

The actualization of democracy as a "way of life" has consequences and great challenges. Everyone should be trained to develop deliberation in decision making, develop the freedom of creativity, and organize their own basic life (Sharma, 2019). It is very difficult to materialize if there is no real actualization through democracy education early and lasts for a long time. Remembering democratic values cannot grow in every society by itself.

Islamic Pesantren as the oldest boarding school in Indonesia serves as the main agent for the mission to be engaged. Considering that in the course of the history of Pesantren proved to be able to change the reality of Indonesian society, not only on the aspect of education but also foster the love consciousness of homeland and as a nation (Royani, 2018). Besides that, Pesantren also has a relationship that cannot be separated from each other based on the democratic value that is compatible with Islamic values. To internalize democracy as the "way of life" in every student, the pesantren must make the whole school life system based on democratic values. 
Every citizen of the pesantren should be to realize the values of democracy in the whole joints of pesantren life, which is actualized in the beliefs, principles, and all the elements that are believed and run by every citizen of the pesantren. In other words, the values of democracy should be internalized in the culture of Pesantren.

If the culture of the Pesantren has contained the values of democracy, then this is the main road to create a democracy education in the boarding school. Kultur Pesantren has a central role in embedding the values of democracy as the "way of life" in students. This is closely related to the fact that the education of Pesantren can create small communities with the boarding system that is run. The Pesantren can design and create a culture of the pesantren community based on democracy. This is the main step of creating a democratic society in the life of community students outside the Pesantren.

At least some Islamic boarding school cultures have to be the values of democracy as the realization of democracy education as "Way of Life" in Pesantren. The values of democracy must be contained in the following matters:

\section{Name of Pesantren}

The name illustrates the identity of everything and will stick to it anytime. If the name is attached to a person or entity then the name will indicate the identity of that person or institution. Each name, be it the place, people and things of life or death have different historical roots and meanings based on an assortment of ways and reasons. The name can reflect the reason why it was given the name so that the name can also be expressed as a goal to achieve in future McCafferty (2018).

If you look at the world of business, it can be named as a brand. In Law No. 15 the year 2001 about the brand, in article 1 paragraph one brand is defined as a sign consisting of images, names, words, letters, numbers, color arrangement or a combination of those elements that have a differentiation power and used in the activities of trading goods or services. So important is the use of names so that countries create rules in recognition of name rights.

So important the meaning of a name, in Islam there is a rule in giving names. Islamic religion governs the naming with a name that has good meanings because the name shows identity and becomes a prayer for the name of the disabled and he will try to behave according to his name.

Based on the explanations above, the most basic way to actualize democracy education through Pesantren culture is to choose the name of Pesantren that can represent the values of democracy. Instead by choosing the name of the pesantren that does not contain the value of democracy will ultimately affect the look of the Pesantren society, such as the use of names that lead to the activities of Islamic radicalism.

Referring to the previous description of the values of democracy, as well as the setting of the name "Assalaam" as the name of the Pesantren, at least can be found 4 democratic values contained in the name. The value is togetherness, peace, justice, and compassion.

Assalaam comes from the word salam or aslama which in Arabic means perfect peace. The use of the name is based on the ideals of boarding schools that want to restore and foster the image of early Islam as a peaceful religion that cool and make peace. With the value contained in the name of boarding, this is PPMI Assalaam instill to every pesantren society to be a person who plays an active, tolerant, and clear thinking full of tranquility.

The word Assalaam can also be like an extremely clean source of water that will purify and replenish the conscience with the seeds of a way of thinking that loves the peaceful. It is hoped that the students of PPMI Assalaam should play the role of the spreading and illuminating lamps for around from the Dark world life and to the happy afterlife in a soothing, calming, and enlightening way.

\section{Vision and Mission of Pesantren}

Vision and mission are the first steps of an organization and the final goal or overall performance of the run. Organizational formation begins with a detailed definition of its vision and mission. Then planning all the effort to be done to the achievement (Wadhwa, 2016).

If referring to the vision and mission of national education in Law No. 20 of 2003 , there are updates to the national education system including the elimination of discrimination between formal education and non-formal education. The vision of national education is to empower all Indonesian citizens so that it can develop into a qualified human being able to compete and also in response to the gaze of the era.

While the national education mission is at least a few points, namely: seeking equitable education for all Indonesians, improving the readiness of input and quality of the education process to optimize the creation of moral personality, to keep the learning facilities for the community from early to the end of life, improve the professionalism of education institutions and involve the community in the implementation of education.

If we look at the application of the vision and mission of the national education above, there is a strong indication that there is a business that leads to democratization in the education process. So the entire vision and mission of each educational institution should refer to it. One way to implement a democracy education in the culture of Pesantren is 
through the establishment of a vision and mission of Pesantren based on democratic values. Establishing the vision and mission of Pesantren in Indonesia should be based on democratic values. This includes fulfilling depart rights for all citizens without distinguishing the race, ethnic and social status, student economics, improving school quality, developing students according to the age and fulfillment of educational facilities needed to support the education of Pesantren.

If the process of internalizing the values of democracy in the Vision dan mission Pesantren has been emtualized, it will create a democratic school culture. This affects the behaviour and attitudes of each student and employee to internalize the values of a democracy (Darbi, 2012). With the impact of appreciation for all the status of the students of Pesantren, then both students and educators will be accustomed to living in the diversity of society by respecting and supporting each other. This affects the students ' life in the real society in the future.

The vision and mission of PPMI Assalaam, The first, the realization of human beings who have a balance of spiritual, intellectual, and moral to the generation of Ulul albab that is a high commitment to the benefit of the people by the foundation of devotion to Allah SWT. While the mission of Pesantren is: first, organizing a process of Islamic education that is quality-oriented, high competitiveness, and based on spiritual attitude, intellectual and moral to realize the cadre of people who become Rahmatan Lil Alamin. Second, develop the working of Pesantren boarding school based on the management of Islamic professionals to create an atmosphere of life in an orderly, safe, and peaceful cottage environment. The third, improve the positive image of the educational institution of Pesantren which is insightful of science and information technology and Islamic modern culture. Given in the present era where the current globalization and liberalization are increasingly affecting the concept of faith and Akhlakul Karimah Society, especially the young generation, and the moral students who have to keep from the various possibilities that influence, one of which is the existence of a very advanced social media communication (Fatimah, 2020).

Based on the vision and mission of PPMI Assalaam, it can be concluded that in vision and mission has been containing democratic values by the vision and mission of national education. If you look deeper, there are also awards for the diversity of student economic status. This is evidenced by the scholarship program for students whose family economy level is low. The fact proves that pesantren students come from various regions in Indonesia and various countries. This condition shows that the award for the student's social status is executed without distinguishing race and ethnic origin.

\section{Values of Pesantren}

The education of democracy conducted through the culture of Pesantren is interpreted as the process of integrating all the values of democracy with all the values that are believed and run by all citizens of Pesantren. So that all activities of citizens of Pesantren will always be based on the value of democracy. In the end, this habituation is the main driving engine of the development of intelligence and understanding of democracy.

Pesantren has a culture that has been developed and run for a long time. When the values of Pesantren have been integrated with democratic values, this will create a democratic Islamic boarding school. The culture of Islamic boarding school includes the values, norms, attitudes or beliefs, hopes, and traditions that exist in the pesantren that will be inherited between generations and are believed to be together will influence the mindset, attitudes, and actions of all the citizens of Pesantren to be democratic. But only the pesantren that is just a democratic berkultur that will actualize the education of democracy successfully.

PPMI Assalaam Apparently embeds the culture of democratic values in the life of the pesantren environment. The culture of boarding school PPMI Assalaam integrated with the values of democracy is imbued throughout the Pesantren society through the creation of the life setting of pesantren based on democracy value. The values of democracy integrated with the culture of Pesantren are the values of democracy that are compatible with Islam as described by Kuntowijoyo (1997), namely: Know each other (Ta'aruf), Deliberation (Syura), cooperation (Ta'awun), profitable communities (Maslahah), fair (Adl), Change (Taghyir), Freedom (Huriyat), and Equality (al-Musawat).

There are seven values of PPMI Assalaam integrated with the value of democracy: the value of the inclusiveness of Pesantren, four characters of peace Pesantren, the teaching idealism of Pesantren, the value of Rahmatan lil'alamin, stood on all groups and the development of cultural criticism. While the value of democracy contained in the life setting of PPMI Assalaam is: Modern concept, Hikmah Tarbawiyah, procurement of social and disciplinary discipline, determination of public facilities of students, activities of the Assalaam Festival and the reception system of new students.

Basically to create a democratic culture of Pesantren as described above can be emtualized by integrating democratic values in two forms the primary value of pesantren, namely the essential value and instrumental value. Essential value is a value built by the initiator and the pioneer of pesantren that becomes an element of pesantren that is inseparable between these values and Pesantren. These values are poured in 4 forms: Vision, Mission, motto, and five Islamic boarding schools. The preparation of vision, mission, motto, and soul is very important because it will show the nature of a pesantren. Based on these four aspects the soul and the role of Pesantren for the people will be represented. The life of boarding schools will also be animated by these values. Integrating the essential values of pesantren and the value of 
democracy will manifest the democratic soul of Pesantren, which is then internalized in the boarding system and the behavior of the community.

The integration of democratic values with instrumental values of pesantren must also be done. The instrumental value is the value that is the implementation guideline of the basic or essential value. Integrating between the two is applied in moral norms that accumulate in institutional philosophy, educational philosophy, philosophy of learning, and orientation of educational boarding schools or those manifested in a direction, policy, or strategy that is sourced at an essential value. Essential and instrumental values integrated with the value of democracy is further implemented in the management of boarding school life. The social settings, boarding activities, the setting of facilities and infrastructure, and the financial setting of Pesantren.

\section{CONCLUSION}

Pesantren as an Islamic educational institution in Indonesia takes a major role in the actualization of democracy education. It concludes that the actualization form of democracy education in the pesantren environment or other educational institutions through school culture is considered most effective. The culture of Pesantren that is always believed and run by every citizen must be designed in such a way as to characteristic democracy. The basic step in this endeavor is to create a boarding identity that contains the spirit of democracy. It was the initial driver to determine the direction of the vision and mission of boarding schools that suited the values of democracy. The need to realize the central role of citizen Pesantren to create a democratic Islamic boarding school can be run with an integration strategy of essential values and instrumental with the values of democracy. Both values are the basis of the behaviour of all citizens. Democratic culture of Pesantren becomes key to the development of the intelligence of citizens of Pesantren will democracy as a "way of life".

\section{IMPLICATION OF THE STUDY}

The results of this study have implications as an evaluation material on the implementation of democracy education on educational institutions, especially pesantren. However, Pesantren has a role in shaping the values of democracy. Evaluation of the implementation of democracy education that has been implemented is presented to increase knowledge treasures as well as generate a prototype of democratic education actualization in the educational institutions, especially pesantren through the development of the democratic pesantren culture.

\section{LIMITATIONS AND STUDY FORWARD}

This research is limited to the development of Islamic boarding school culture as the basis for the actualization of democracy education in pesantren or other educational institutions. There are still two main elements to create a holistic education of democracy, which is the structure and process of the educational institutions. For this reason, it is recommended to conduct further studies on both of these matters.

\section{ACKNOWLEDGMENT}

We are grateful to Menejement of Islamic Modern Boarding School Assalaam Surakarta, Central Java, Indonesia which has received us to do research on democracy education through the development of Pesantren culture.

\section{AUTHORS' CONTRIBUTION}

The first authors contributed in the process of collecting data, studying the entire data, reducing data, arranging in units, categorizing data validity checks, data interpretation, and lastly compiling the research results. The second authors contributed to the preparation of research plans and data collection assistance. The third writer contributed to evaluating the data analysis process

\section{REFERENCES}

1. Aasebø, T. S., Midtsundstad, J., \& Willbergh, I. (2015). Teaching in the age if accountability: Restrained by school culture?. Journal of Curriculum Studies, 49(3), 273-290. https://doi.org/10.1080/0 $\underline{0220272.2015 .1072249}$

2. Aly, A. (2011). Pendidikan Islam Multikultural di Pesantren, Telaah Terhadap Kurikulum Pondok Pesantren Modern Assalaam Surakarta. Yogyakarta: Pustaka Pelajar.

3. Sabic-El-Rayess, A. (2020). Epistemological shifts in knowledge and education in Islam: A new perspective on the emergence of radicalization amongst Muslims. International Journal of Educational Development 73(1), 110. https://doi.org/10.1016/j.ijedudev.2019.102148

4. Apergis, N. (2018). Education and democracy: New evidence from 161 countries. Journal Economic Modelling 71, 59-67. https://doi.org/10.1016/j.econmod.2017.12.001

5. Darbi, W. (2012). Of mission and vision statements and their potential impact on employee behaviour and attitudes: The case of a public but profit-oriented tertiary institution. International Journal of Business and Social Science. 14(3). 95-109.

6. Aubusson, P., Watson, K., Vozzo, L., \& Steele, F. (2005). Retrained teachers and school culture: Complex interactions. Teacher Development, 9(1), 59-77. https://doi.org/10.1080/13664530500200241 
7. Azra, A. (2003). Pendikan Kewargaan: Demokrasi, HAM dan Masyarakat Madani. Jakarta: Prenada Media.

8. Azra, A. (2015). Civil education at Public Islamic Higher Education (PTKIN) and pesantren. Jurnal of Education in Muslim Society, 2(2), 167-177. https://doi.org/10.15408/tjems.v2i2.3186

9. Baise, M. (2003). Doing democracy in social studies methods. Theory \& Research in Social Education, 31(1), 51-71. https://doi.org/10.1080/00933104.2003.10473215

10. Cho, Y. (2014). How well ordinary citizens understand democracy: The case of the South Korean electorate. Democratization, 21(2), 195-219. https://doi.org/10.1080/13510347.2012.734808

11. Coffe, H. (2014). Education and support for representative, direct and stealth democracy. Journal Electoral Studies, 35, 1-11. https://doi.org/10.1016/j.electstud.2014.03.006

12. Glaeser, E., Ponzetto, G., \& Shleifer, A. (2006). Why does democracy need education?. National Bureau of Economic Research, 1-45. https://doi.org/10.3386/w12128

13. Fatimah, M., Sutama., Aly, A. (2020). Religious culture development in community school: A Case Study Of Boyolali Middle School, Central Java, Indonesia, 8(2). 381-388. https://doi.org/10.18510/hssr.2020.8243

14. Freedman, A., \& Tiburzi, R. (2012). Progress and caution: Indonesia's democracy. Asian Affairs: An American Review, 39 (3), 131-156. https://doi.org/10.1080/00927678.2012.704832

15. Gandal, M., \& Finn, Jr, C. E. (1992). Freedom Papers : Teaching Democracy. USA : United States Information Agency.

16. Garmston \& Wellman. (2013) The adactive school: A sourcebook for developing collaborating groups. Maryland: Rowman \& Littlefield Publisher.

17. Giroux, H. A. (2008). Education and the crisis of youth: Schooling and the promise of democracy. The Educational Forum, 73(1), 8-18. https://doi.org/10.1080/00131720802539523

18. Hansen, D. T., \& James, C. (2015). The importance of cultivating democratic habits in schools: Enduring lessons from democracy and ducation. Journal of Curriculum Studies, 48(1), 94-112. https://doi.org/10.1080/00220272.2015.1051120

19. Indrawati, N. (2014). Management by inspiration: Implementation of transformational leadership on business at pondok pesantren*) Sunan Drajat. Procedia - Social and Behavioral Sciences, 115, 79-90. https://doi.org/10.1016/j.sbspro.2014.02.417

20. Jwana, J., Anderson, L., \& Bennett. (2010). Democratic school leadership reforms in Kenya: Cultural and historical challenges. Journal Of Educational Administration and History, 42(3), 247. https://doi.org/10.1080/00220620.2010.492962

21. Karakuş, M. (2017). An investigation of students perceptions about democratic school climate and sense of community in School. Universal Journal of Educational Research, 5(5), 787-790. https://doi.org/10.13189/ujer.2017.050511

22. Kuntowijoyo. (1997). Indentitas Politik Umat Islam. Bandung: Mizan.

23. McCafferty, M. (2018). Kokomo: The history and meaning of a remarkable and elusive. Names: A Journal of Onomastics, 66(2), 75-84. https://doi.org/10.1080/00277738.2017.1415535

24. McDonnell, J. (2013). Reimagining the role of art in the Relationship between democracy and education. Journal of Educational Philosophy and theory, 46(1), 46-58. https://doi.org/10.1111/j.1469-5812.2011.00802.x

25. Minkenberg, M. (2007). Democracy and religion: Theoretical and empirical observations on the relationship between Christianity, Islam and Liberal Democracy. Journal of Ethnic and Migration Studies, 33(6), 887-909. https://doi.org/10.1080/13691830701432731

26. Mulyasa, H. E \& Aryani, W.D. (2017). Developing religious culture in school. The International Journal Of Scienctific \& The Chnology Research, 6(7), 263-267.

27. Munck, G. L. (2016). What is democracy? A reconceptualization of the quality of democracy. Democratization, 23(1), 1-26. https://doi.org/10.1080/13510347.2014.918104

28. Oelkers, J. (2017). The european crisis and education for democracy. The European Legacy, 22(7-8), 832-843. https://doi.org/10.1080/10848770.2017.1368781

29. Paryono. (2018). Pondasi Hukum Peradaban Barat : Pengaruh Terhadap Pengaturan Serta Penguasaan Sumber Daya Alam dan Energi, Dalam Pemikiran Hukum Profetik: Ragam Paradigma Menuju Hukum Berketuhanan. Yogyakarta: Ruas Media.

30. Patriadi, H. B., Bakar, M. Z., \& Hamat, Z. (2015). Human security in local wisdom perspective: Pesantren and its responsibility to protect people. Procedia Environmental Sciences, 28, 100-105. https://doi.org/10.1016/j.proenv.2015.07.015

31. Preskill, S. (1997). Discussion schooling, and the struggle for Democracy. Theory \& Research in Social Education, 25(3), 316-345. https://doi.org/10.1080/00933104.1997.10505810

32. Quay, J. (2016). Not “democratic education” but "democracy and education": Reconsidering Dewey's oft misunderstood introduction to the philosophy of education. Educational Philosophy and Theory, 48(10),1-17. https://doi.org/10.1080/00131857.2016.1174098

33. Ramli, M. (2017). Manajemen dan kepemimpinan pesantren: Dinamika kepemimpinan kiyai di Pesantren. Jurnal Al-Falah, 17(32), 128-140.

34. Royani, A. (2018). Pesantren dalam bingkai sejarah perjuangan kemerdekaan Indonesia. Journal Of Islam Nusantara. 2(1), 121-128. https://doi.org/10.33852/jurnalin.v2i1.75 
35. Sanli,O. (2015). The significane of establishing democratic education environmet at School. Journal Of Education And Instructional Studies In The World, 5(2), 1-8.

36. Schipper, T, M ., de Vries, S., Goei, S. L., \& van Veen, K. (2019). Promoting a professional school culture through lesson study? An examination of school culture, school conditions, and teacher self-efficacy. Professional Development in Education, 1-18. https://doi.org/10.1080/19415257.2019.1634627

37. Schoeman, M. (2010). Education for Democracy. South African Journal of Philosophy. 29(2), $132-139$. https://doi.org/10.4314/sajpem.v29i2.57056

38. Sharma, S. (2019). Democratic values, freedom, control, and life satisfication. Economic Affairs. 64(1), 217231. https://doi.org/10.30954/0424-2513.1.2019.26

39. Storm, L. (2008). An elemental definition of democracy and its advantages for comparing political regime types. Democratization, 15(2), 215-229. https://doi.org/10.1080/13510340701846301

40. Ubaedillah, A. (2018). Civic education for muslim students in the era of democracy: Lessons learned from Indonesia. The Review of Faith \& International Affairs, 16(2), 50-61. https://doi.org/10.1080/15570274.2018.1469837

41. Wadhwa, S. (2016). Impact of vision and mission on organizational performance in Indian context. The International Journal Of Business \& Management, 4 (12), 156-170.

42. Waghid, Y. (2014). Islam, democracy and education for non-violence. Ethics and Education, 9(1), 69-78. https://doi.org/10.1080/17449642.2014.890327

43. Wekke, I. (2014). Arabic teaching and learning: A model from Indonesia muslim minority. Procedia-Social and Behavior Science, 9(1), 69-78. https://doi.org/ 10.1016/j.sbspro.2015.04.236.

44. Gao,Y, G., Zang, L, Z., Roth, A., \& Wang, P. (2017). Does democracy cause innovation? An empirical test of the popper hypothesis. Research Policy, 46(7). 1-12. ttps://doi.org/10.1016/j.respol.2017.05.014

45. Zamroni. (2011). Pendidikan Demokrasi pada Masyarakat Multikultural. Yogyakarta: Bigraf Publising. 